\title{
Political Dimension in Pan-African Cross-border Banking: An Inhibitor or Catalyst?
}

\author{
Okoche Michael \\ Correspondence: Okoche Michael, Uganda Management Institute, P.O Box 20131, Jinja Road, Kampala, Uganda. \\ E-mail:okochem@gmail.com
}

Received: December 12, 2018 Accepted: January 9, 2019 Online Published: January 21, 2019

doi:10.11114/bms.v5i1.3984

URL: https://doi.org/10.11114/bms.v5i1.3984

\begin{abstract}
The emergence and the dominance of African banks in Africa have been touted as one of the popular mechanisms for financial development leading to a concept termed as Pan-African cross-border banking. African Banks have become dominant in the African market as opposed to European colonial banks substantially increasing their geographic footprints on the continent. African banks have become economically significant beyond their home countries and of systematic importance in a number of jurisdictions. This systematically examined the influence of the political environment on Pan-African cross-border banking using Kenya Commercial bank as a case study.

Interpretive research paradigm guided the study seeking using qualitative data by interviewing employees, managers, and policymakers from the three subsidiaries of Kenya Commercial Bank; Uganda, Rwanda, and Burundi. This was further supported by secondary data collected from journal articles and reports from the Kenya Commercial Bank.

The study established that political environment plays an important role in influencing Pan-African cross-border banking either through catalysing or inhibiting. Despite effort integration by African Union, regional unions like East African Community there still areas for improvement. In order to enhance Pan-African cross-border banking, there has to be systematically management of political environment which was distorted by history, ideologies, different political systems, different regulatory frameworks between the subsidiaries and home countries. This will further enhance the significance of Pan-African banks African cross-border banks enhancing economic development within Africa.
\end{abstract}

Keywords: Pan-African, Pan-Africanism, cross-border banking, catalyst, an inhibitor

\section{Introduction}

Host and home country regulatory environment diversely influences the cross-border strategy and competitiveness of cross-border bank. Multinational Enterprises jurisdiction and organisational structures are paramount in the development and implementation of the cross-border business strategy (Windsor, 2007). Getz (2006) highlights that the political environment in different jurisdictions determines the strategy. MNEs are fragmented along global, regional, national, and sub-national regulatory dimensions (Windsor, 2007). Bonardi, Hillman, and Keim (2005) argue that each regulatory arena becomes a political market where demand and supply depend on the prevailing regulatory in the jurisdiction. Svaleryd, Hakkala, and Norback (2005) argue that domestic firms are more effective than international firms because of their knowledge of and alignment to domestic policies. Managers responsible for the development of an international strategy will have to face many different types of political, legal, accounting, cultural, language, and payment systems (Diaconou, 2012). According to Gooderham (2013) MNEs are confronted by political environments in both domestic and foreign countries. Lundan (2014) argues that diverse forms of governance structures make operations of MNEs across borders a bigger challenge than domestic operations. Gooderham (2012) opines that undertaking cross-border trade without incorporating firms' responses to national policies and actions results in failure because government interventions are central to cross-border trade. Governance structures together with policies of the home and subsidiary countries influence the strategies employed by MNCs (Lundan, 2014). Cross-border involves following a regulatory discipline that encompasses a firm's business environment together with government policies (Camillo, 2015). The political environment provides a critical context for MNEs at home and abroad (Shenkar and Luo, 2008: 184). Governments are responsible for trade and investment policies, capital, and exchange controls and transfer pricing regulations (Diacanou, 2012). Home and host countries regulatory environments significantly contribute to greater certainty with regard to predictability and consistency in implementation, a significant reduction in compliance costs across the region, and 
raising standards in more challenging environments and emergence of international and global strategy. Frameworks in the home and host country influence the strategy and competitiveness of cross-border banking (Becks et al., 2014).

The study to undertake an assessment of pan-African cross-border competitiveness was assessed by assessing the different elements that influence the political environment in the subsidiary and home country. Different aspects of political environments were examined by use of qualitative statements. The political elements in the subsidiary and home country include; regulatory frameworks, monitoring, and supervision, a collaboration between regulators, political stability, political system, political ideology, political history, a judicial system, social norms, and cultural norms. Gooderham (2013) argues that MNEs have to deal with the political and socio-cultural environment in both domestic and foreign countries. The major emphasis was to understand the participant's point of view, interpretation and the rational approach, observations and measurements in natural settings, subjective and insider view and closeness to the data.

\section{Methodology}

The study used the case study research design based on interpretive research philosophy. Qualitative methodologies are popular in social sciences for validation of models as it provides the researchers with the ability to understand the experiences of the respondents (Strauss \& Corbin, 1998; Ghauri\&Gronhaug, 2003). McGloin (2008:45) argued that qualitative research is concerned with the explanation of a social phenomenon focusing on people's behaviour being the effect of events on people, cultural influence, developments and differences in social groups. Qualitative study facilitated the expression of experiences which couldn't be expressed in numbers (Strauss \& Corbin, 2003, Berg, 1989). It emphasized understanding from the participant's point of view, interpretation and the rational approach, observations and measurements in natural settings, subjective and insider view and closeness to the data in relation to the impact of political environment on competitiveness by a cross-border bank.

IMF (2017) argues that despite the global financial crisis, Africa has witnessed a rapid expansion of cross-border banking, led by banking groups based in Africa that are spurring financial and economic integration and transforming the continent's financial landscape. Pan-African banks have become economically significant beyond their home countries and of systematic importance in a number of jurisdictions. Pan-African banks have become significant in the different regions; Nigerian Banks in West Africa, South African Banks in South African Development Community (SADC) countries and Morrocan Banks in North Africa. Kenya Commercial bank was used as a case for studying cross-border banking as the phenomenon was similar where regional banks had influence within the different regions. The approach enabled the researcher to explore operations of Kenya Commercial bank in the four countries covered by the scope of this research. This enlightened the researcher on the insights of the holistic behaviour and regulatory environments in Kenya, Uganda, Rwanda, and Burundi.

The researcher interviewed employees, policymakers, and regulators of Kenya Commercial Bank form Uganda, Rwanda, and Burundi subsidiary branches. The studies focused on these are the major developers of strategy with an understanding of competitiveness in cross-border banking. This was further supported by secondary data collected from journal articles and reports from the Kenya Commercial Bank.

\section{Findings}

\subsection{Regulatory Framework Impact on Cross-border Strategy and Competitiveness}

Regulatory framework constitutes requirements, restrictions, guidelines that are established by the central banks in different jurisdictions in order to maintain the integrity of the monetary system. The subsidiary and home regulators undertake the process of regulating the banking in the different jurisdictions. The quantitative part of the study provided insight that subsidiary and home regulatory frameworks are critical influence strategy and competitiveness. Most of the respondents interviewed argued that regulatory frameworks in the different jurisdictions are critical in influencing the actions of banks in different jurisdictions.

Subsidiary regulatory frameworks are critical for the development of a strategy in cross-border banking. One of the employees opined that "the regulatory framework shapes the business environment which the bank operates in the policies adopted by the Bank of Rwanda has an impact on the strategies adopted by the bank. The current policy adopted by the bank of Rwanda making its mandatory for all deposit-taking institutions to pay premium has increased the cost of doing business. This definitely influences the strategy and competitiveness."Gooderham (2012) opines that undertaking cross-border trade without incorporating firms' responses to national policies and actions results in failure because government interventions are central to cross-border trade. Governance structures together with policies of the subsidiary countries influence the strategies employed by MNCs (Lundan, 2014). Peter one of the subsidiary manager in one of the countries submitted the regulatory mechanisms adopted are critical. In his argument said that "the regulatory framework basically forms standards that all the players in the market have to use for playing. Failure to adhere to the regulations attracts penalties which are not good for business." Getz (2006) highlights that the political environment provides formal 
arrangements that determine the strategy. MNEs are fragmented along global, regional, national, and sub-national regulatory dimensions (Windsor, 2007). Bonardi, Hillman, and Keim (2005) argue that each regulatory arena becomes a political market where demand and supply depend on the prevailing regulatory in the jurisdiction. Deficient contractual framework curtails the ability of financial institutions to enforce contracts and therefore undermining the cross-border contribution to the financial system influencing competitiveness and strategy (Beck et al., 2014).

Qualitative findings also highlight that home-based regulatory frameworks are critical in the determination of the political environment of headquarters. The process of development of strategy and competitiveness of the cross-border bank is undertaken in the headquarters. The process of undertaking cross-border banking is provided for the circumstances in the political environment in the home country. Shenkar \& Luo (2008:184) argue that "regulatory environment at home and abroad as critical for cross-border banking strategy and competitiveness". Political environments provide contexts for competitiveness and the ground for the firm to follow. Governments are responsible for trade and investment policies, capital, and exchange controls and transfer pricing regulations (Diaconou, 2012). Home and host countries regulatory environments significantly contribute to greater certainty with regard to predictability and consistency in implementation, a significant reduction in compliance costs across the region, and raising standards in more challenging environments and emergence of international and global strategy. One of the employees interviewed argued that "regulators in the different jurisdictions have different guidelines to be followed for successful competition. In the Republic of South Sudan, the regulator has conditions that the South Sudanese citizens can't be paid outside Sudan borders; the different jurisdictions also have different legal requirements for liquidity and cash ratios in the different countries. These strategies have different implications on strategy and competitiveness". Frameworks in the home and host country influence the strategy and competitiveness of cross-border banking (Becks et al., 2014). Another subsidiary manager in one jurisdiction explained the process of shaping the strategy by arguing that "the bank mainly survives through commissions and the bank avoids incurring losses by payment of penalties to regulators that have negative consequences to the success, survival, and competitiveness of the bank". The penalties charged by regulators have negative consequences on the bank success this shapes the strategy adopted by the bank as the employees are focused on meeting targets which have been set.

The cross-border seeking to gain competitiveness has to understand the regulatory frameworks in both subsidiary and home country jurisdictions. This facilitates in the process of developing an appropriate strategy mindful of regulatory frameworks in the different jurisdictions. Understanding of different frameworks supports both strategy and competitiveness in a cross-border bank.

\subsection{Impact of Monitoring and Supervision on Cross-border Banking}

The central banks undertake monitoring and supervision of financial institutions in the different jurisdictions in order to ensure adherence to the regulatory frameworks in respective countries. Cross-border bank operating in the different subsidiaries will be faced with different regulators undertaking supervision. The regulator establishes standards and guidelines on the different aspects of financial prudence; core principles of effective banking supervision, standards on capital adequacy. The study findings highlighted that monitoring and supervision undertaking by the subsidiary and home regulator influence the strategy adopted and competitiveness of the cross-border bank. Monitoring and supervision are critical in the execution of countries regulatory framework.

The process of ensuring that the players in the financial sector play by the rules and regulations stipulated critically determines the strategy adopted. One of the subsidiary managers argued that "actions of the regulators determine the strategy and competitiveness of the bank. He argues the penalties and sanctions that come with monitoring and detrimental for the bank success, therefore pushing banks towards coming up with appropriate strategies which for success". He said that the penalties erode the profitability of the bank and this pushes the subsidiary and headquarters to take due care of the strategies to be undertaken. Host countries regulatory framework drives the cross-border banking strategy; exchange rates, level of trade for the home country (Goldberg and Saunders, 1980), regulations of in the host countries (Buch, 2003; Herrero and Pería, 2007), size of the bank, effective lending rate differentials, size of host banking market (Cho, 1986), size of the home country, level of home country FDI (Fisher and Molyneux, 1996), expected growth and degree of openness and diversification potential of host market, and efficiency of the subject bank (Focarelli and Pozzolo, 1999).The subsidiary regulators usually play a traditional role of protecting and safeguarding their financial institutions and banking systems, taking into consideration the risks associated with the growth of cross-border activity in recent years (Becks, Fuchs, Singer and Makaio, 2014). This forces them to put in place mechanisms for the prudent management of monetary policy within the jurisdiction.

Qualitative data provides insight that home-based monitoring and supervision influence strategy and competitiveness. The regulatory framework together with supervision influence the strategy adopted. The legal requirements in the home country in terms of liquidity and other performance standards influence the strategy adopted in the headquarters. One of the headquarters respondents argued that "the parent bank usually is influenced by the home regulator in terms of a 
strategy adopted to undertake operations in the home country. However, the process at home can have a bearing on the strategies adopted in the subsidiaries. This is because these mechanisms can free up capital for further investment in the subsidiaries. The practices learned in the home country, and the method of doing things usually are a template that will be first used in the subsidiaries." The depth of the home country banking system expands business opportunities which enable banks to offer more innovative products to exploit profit opportunities locally rather than expand abroad fully (Focarelli and Pozzolo (2005). Schoenmaker and van Laecke (2007) argue that deeper banking systems provide banks with a steady income at home that enables them to finance cross-border operations and competitiveness. The regulators of the home will always work towards the establishment of home conditions which enhance banking growth at home and in foreign countries.

Monitoring and supervision in the subsidiary and home country influence the strategy and competitiveness in cross-border banking. However, subsidiary monitoring in the subsidiary is more critical for cross-border competitiveness. This implies that cross-border bank undertaking cross-border banking has to be mindful of both subsidiary and home regulatory supervision in the process of development of the cross-border strategy for competitiveness.

\subsection{Impact of Regulators Collaboration on Cross-border Banking}

Basel Committee on Banking Supervision (BCBS) established in 1974 provided a forum for regular cooperation between regulators (Gattani, 2014). The Basel Committee provides a framework for cooperation establishes standards and guidelines for international standards on capital adequacy, core principles for effective banking supervision and concordat on cross-border banking supervision. The regulators released norms for regulation of the banking sectors using different standards; Basel 1-1988, Basel II-2004 and Basel 3-2010. The norms established to provide a framework for collaboration between the subsidiary and home-based regulators. Basel III established due to the failure of Basel II to adequately deal with the global financial crisis of 2008 (Gattani, 2014).

Collaboration between the home and subsidiary regulators; the process of monitoring and supervision has become critical especially after the financial crisis in the USA that affected economies in different countries. Beck et al., (2014) argue that cross-border banks that are driven by regional integration provide potential channels of risks associated with the integration of financial systems as a result of increased linkage between the banking systems and financial markets these allows transmission of shocks across borders. Regulatory authorities in a subsidiary and home countries, therefore, have to develop appropriate frameworks for the management of risks from cross-border banking due to an emerging trend of interwoven financial systems as a result of cross-border banking. One of the regulators argued that "the process of supervision of cross-border banks require collaboration as the home-based supervisors and subsidiary supervisors are usually guided by the same benchmarks of a stable monetary policy in the home country. She highlighted that whereas the home-based supervisors are concerned about the challenges in home economies but regional challenges can easily be transferred to the subsidiaries or home country. The process of collaboration facilitates the development of appropriate mitigation mechanism in advance".

However, the cross-border banks and regulators need to provide adequate risk management and mitigation mechanisms (Beck et al., 2014). Management of risks as a result of cross-border banking calls for "a greater commitment and adherence to common rules of the game, as embodied in internationally accepted standards and practices, in order to foster greater confidence in the financial sectors on the continent" (Becks, Fuchs, Singer and Makaio, 2014). Collaboration facilitates the process of building appropriate networks for appropriately dealing with risks across the borders. One of the respondents argued that "the current economic crisis in Uganda and the East African regulators have to put in place mechanisms for dealing with contagion. The failure of banks in Uganda like Crane bank calls for the regulators in the different jurisdictions to focus on critical supervision and monitoring and being mindful of spillover effects or contagion to the different subsidiaries."

Home regulators in the process of regulating the bank in the home country influence the strategies adopted by the bank both at home and in the subsidiaries.Becks et al. (2014) argues that in order to provide a competitive regulatory environment, authorities have to develop appropriate platforms and formats for regular information interchange with data providing for i) basic quantitative and qualitative characteristics of cross-border banks ii) supervisory data in relation to performance iii) regulatory frameworks with definitions underlying supervisory data and market intelligence. Regulatory harmonisation is a huge undertaking, and care needs to be taken to focus convergence efforts on key concerns, especially in environments with severe capacity constraints (Beck et al., 2014). They advocate for upgrading of mechanisms by regulators by use of strategies like consolidated supervision of a bank's activities through all its affiliates, across sectors and jurisdictions; Memoranda of Understanding (MoU) between home and host supervisors; and Colleges of Supervisors $(\mathrm{CoS})$ for individual cross-border financial institutions, are the basis for effective cross-border regulatory cooperation.

In order for Kenya Commercial Bank to be competitive, the bank has to respond to the subsidiary and domestic home regulators effectively. Collaboration facilitates the integration of the regulatory and supervisory responsibilities of the home and subsidiary regulators. The cross-border bank seeking to gain competitiveness has to appropriately understand 
the collaboration between the subsidiary and headquarters in order to appropriately respond to the requirements.

\subsection{Influence of Political Stability on Cross-border Banking}

Political stability determines the integrity and durability of a current government regime, measured by the amount of violence and other forms of instability in the nation. Subsidiary and home country political stability are critical in the determination of the atmosphere for banking. Political instability affects the level of economic activity in the jurisdictions.

Qualitative findings agree with quantitative findings that cross-border strategy influences strategy and competitiveness in cross-border banking. Most of the respondents interviewed highlighted that the political stability is critical in determining the strategy which is adopted by the bank. One of the managers in the headquarters in his statement opined that "the political instability in Kenya in 2007 greatly affected the operations within the country. He said that since the headquarters was the driver of most of the operations of the bank, it adversely affected the strategies and competitiveness of bank especially against those banks from other countries". The headquarters are critical in the process of coming up with appropriate strategies and coordination of operations of the subsidiaries. Political instability in the home country substantially affects the strategy employed and competitiveness of the bank.

Subsidiary political stability is equally important in the development of strategy and competitiveness of the bank. One of the regulators interviewed highlighted that currently there are two countries experiencing political instability; Southern Sudan and Burundi. He said that "political instability South Sudan led the bank to close branches and repatriation of the staff from the Country". It's imperative to highlight that political instability in the subsidiary influences cross-border strategy and competitiveness. This is in agreement with findings by KCB (2016) highlighting the poor performance of the bank in Burundi. Burundi's economy has experienced pressure as a result of the political crisis that engulfed the country resulting in poor economic performance, therefore, affecting the banking sector (KCB, 2016). The World Bank indicates that Burundi's economic growth contracted by 2.3\% in 2015 compared to a GDP growth of $4.8 \%$ in 2014, coupled with an increase in inflation from $3.5 \%$ to $7.1 \%$ as a result of an increase in consumer goods. The treasury bills rates have doubled in the middle of 2014 before finally declining.

Development of an appropriate strategy for competitiveness requires an assessment of the subsidiary and home country political stability. The bank has to continuously undertake an assessment of the political stability of the home and subsidiary for competitiveness in cross-border banking.

\subsection{Influence of Judicial System on Cross-Border Banking}

The judicial system is the court system provided in the different jurisdictions for interpretation and application of laws in the different countries. The system provides mechanisms for resolution of disputes in the different jurisdictions. The quantitative study undertaken in the first part of the study argued that the judicial system was not critical in the determination of cross-border strategy, but qualitative study pointed out that judicial system is critical in the determination of the strategy and competitiveness in cross-border banking.

Most of the respondents interviewed during the second part of the study argued that the judicial system in the subsidiary and home country are critical for strategy and competitiveness. The respondents argued that the judicial system is critical in the litigation process in case of breach of contracts. One employee in Rwanda argued that "the courts are the temples of justice lack of justice will automatically lead to failure in the banks". The judicial system in the subsidiary and home country provides a backbone for justice to execute. CSU (2010) argues that a good court system sustains firms' expectation that their contractual rights would be honoured in the face of contract breach, allowing them to commit necessary investments and to expand without worrying about contract reneging. Academic literature in law, economics, and finance emphasize the importance of effective contract enforcement to economic performance (Cooter and Ulen, 1988; La Porta et al., 1996). The concept has become more critical especially with the emergence a notion that judicial systems in the different jurisdictions had different implications on the development of the credit market and economy. The findings are in agreement with Cristini et al., (2001:28) in the study of Argentina established that "the country's federal structure places responsibility for enforcing these regulations in the hands of independent judiciaries. Local courts took a variety of approaches to enforcement, leading to regional differences in access to credit". The study further established that the judiciary imputed different costs across different jurisdictions bringing in place difficult mechanisms for resolution of conflicts. It's imperative to note that whereas the judicial system indirectly influences the development of the strategy and competitiveness in cross-border banking. This is as a result of the divers' judicial systems imputing different costs to the penalties and strategy implementation.

Cross-border banking developing a cross-border strategy has to undertake an assessment of the judicial system of the subsidiary and home country - the dynamics in the different jurisdictions influence strategy especially in the process of litigation. The bank has to continuously undertake an assessment of the judicial systems of the home and subsidiary for competitiveness in cross-border banking. 


\subsection{Influence of Political Ideology on Cross-border Strategy and Competitiveness}

Political ideology is an assortment of principles, ethical ideals, myths, doctrines, symbols of a social movement, class, institution, large group explaining how society should work and offering particular political blueprint for a particular social order (McClellan, 1986); rules of the game in the notion of institutional theory used in understanding economic and political systems worldwide that is neither the rules nor the enforcement of those rules is necessarily identical (North, 1991). The political ideology of the home and subsidiary countries are argued to provide a playing ground for the development of a political system which is critical in the emergence of a strategy. A majority of the respondents interviewed during the qualitative part of the study argued that political ideology influences strategy, subsequently cross-border competitiveness. Academic literature has demonstrates how both formal and informal institutions affect outcomes (Kormendi and Meguire, 1985; Knack and Keefer, 1995; Kaufmann and Kraay, 2002; Zak and Knack, 2001; Beugelsdijk et al., 2004) economic growth, (Anderson and Marcouiller, 2002; de Groot et al., 2004) competitiveness.

The cross-country variation, therefore, brings into play the diverse institutional set up with different political dynamics as a result of political ideologies across the different jurisdictions. This substantially results in the variation in institutions, governance structures resulting in variation of political and cultural environments in the different jurisdictions (La Porta et al., 1997; Paldam, 2001; Knack and Zak, 2002). Quantitative finding highlighted that political ideology in the home country didn't influence the cross-border strategy and competitiveness. However, the qualitative findings seemed to argue that political ideology is responsible for the emergence of the cross-border strategy and competitiveness. One of the respondents in his argument said that "a look at the East African community may look the same, but the countries have different political ideologies that influence the business interactions in the East African countries. Tanzania basically tends to follow the Ujamma political ideology which emphasizes togetherness. Rwanda having emerged from the genocide has taken on strong stance towards respect of authority. The ideologies seem to shape the views of the citizens. The banks have to understand the political ideologies responsible for shaping institutions." Political ideology is an underlying variable which shapes the political and socio-cultural environments in the different jurisdictions. This is in agreement with Mullins (1972: 510) defined political ideology as "a logically coherent system of symbols which, within a more or less sophisticated conception of history, links the cognitive and evaluative perception of one's social conditionespecially its prospects for the future - to a program of collective action for the maintenance, alteration or transformation of society."

Political ideologies of the subsidiary and home countries are critical in the determination of the political landscape which the cross-border banks. The landscape in the different territories provides for the establishment of appropriate strategies and competitiveness. Managers of cross-border banking have to understand political ideologies governing subsidiaries and headquarters appropriately.

\subsection{Impact of Political Systems on Cross-border Strategy and Competitiveness}

The political system provides for a coordinated set of laws, principles, ideas, and procedures in relation to a form of government in a given country. The mechanism for coordination of a government in the different jurisdictions provides different political environments for the cross-border bank.

Most of the respondents at the headquarters and subsidiaries argued that the political systems are critical in the determination of the strategy and competitiveness. One of the headquarters managers in charge strategy argued that; "systems employed by the government either liberalization or centralization is critical in the decision of the bank to establish and the extent of intervention in a particular economy". The political system consisting of the principles, laws, ideas, and procedures are critical in determining the decision of investors. The rule of law, for instance, is critical in determining the investors or the bank's decision on how to invest and the form of organisation to invest. The political system provides for institutions formal and informal institutions provide the necessary fabric; the level of trust, social capital, and social network (Knack and Keefer 1997; North 1990; Shirley 2008; Zak and Knack 2001) facilitating transactions relationships. The political system provides a mechanism, such as government policies and behaviours related to the provision of infrastructure, tax burdens, and protection of property rights, labour, and entry regulations (World Bank 2005).

One of the respondents from Uganda argued that "the liberalisation of Ugandan economy triggered the emergence of cross-border banks like Kenya Commercial bank and United Bank of Africa, and Stanbic Bank”. Li and Xu (2002) argue that deregulation was critical for the emergence of new players in the telecom industry. African economies in the 1980s in the process of experiencing economic crises as a result of both poor domestic policies and external shocks liberalized their economies (Becks et al., 2014). Many state-owned banks became insolvent due to political pressure to make unsustainable loans, but also because of the lack of technical expertise and poor management (Brown bridge and Harvey, 1998).

However, different dynamics in different jurisdictions continued to shape the landscapes in different countries in some African countries especially Nigeria and Kenya the legislation for lower banking requirements enabled the local banks to 
gain competitiveness by returns in sectors like foreign exchange (Becks et al., 2014). Specifically in Kenya prudent management and strong market position of Kenya Commercial Bank, control by government, vibrant competition from the private, spurred innovation and, in the 2000s, provided a platform for cross-border expansion in East Africa (Brown Bridge and Harvey (1998).

The political system, directly and indirectly, influences the strategy in cross-border banking as the players involved in cross-border banking usually play to the rules of the game that have been put by the government of the day. Policies and regulations are a reflection of the political system as the system provides for the actors and the mechanisms that determine the mechanisms of engagement. In order develop an appropriate strategy and gain competitiveness the cross-border bank has to systematically understand the political system in the different jurisdictions and come up with a strategy that effectively exploits the unique attributes of the different political environments.

\subsection{Influence of Political History on Cross-border Strategy and Competitiveness}

Political history involves an understanding of a history of political events or affairs; an analysis of history in political terms. Analysis of political history in the subsidiary and home country is significant in the contribution towards the political environment of a country. Political history in the current subsidiaries provides insight similarities and differences in the colonial masters, colonisation process, way to independence, post-independence politics, political parties, and post-independence dynamics. An assessment of political parties internal weaknesses, organisational skills, political ideologies, levels of tolerance, structures, membership, the dependence of individuals, cliques, and the process of independence is critical in the development of the prevailing political environment. Quantitative findings highlighted that political history in the subsidiary and home countries doesn't influence strategy and competitiveness.

However, the qualitative findings provided a different picture as most of the respondents believed that the current political environments in East African countries are a reflection of the political history of the different countries. One of the political leaders interviewed during the study argued that "the different East African Countries which Kenya commercial Bank is currently operating is a clear reflection of the political history of the countries. He said Tanzania was historically under communism and the people's political ideology is unison and Kenya which went valued capitalism has a cultural orientation of domineering in business and Uganda was in between. He further argued that countries like Rwanda and Burundi which emerge from French legal system and of recent Rwanda going Anglophone have a mix of two cultural orientation political history end up shaping the political climate of a nation. Political dynamics in the subsidiaries and home countries basically reflect historical phenomenon. The process of understanding current political climates involves unearthing the political history of a country.

Beck et al. (2014: 189) argue that "at the time of independence, most African countries had banking systems dominated by foreign-owned banks from outside African continent and British banks dominated in the British colonies, while French banks did so in the French and Portuguese banks in the Portuguese colonies". This was partly due to political reasons, and a deliberate outcome negotiated by banks to preserve their market share and avoid competition in order to extract rents (Austin \&UgochukwuUche, 2007). Cross-border banking was shaped by regulatory frameworks favouring former colonial masters to continue doing business in the former colonies.

However, in Uganda and Ghana foreign banks maintained their presence unlike Nigeria, Kenya, and Malawi the foreign banks maintained majority shares, but the importance of these banks decreased with the emergence of new state-owned with local private banks (Brownbridge and Harvey (1998). Political history significantly shaped the concept and dynamics of cross-border banking in Africa.

The political history of the subsidiary and home countries shapes the dynamics of the new political environment. The subsidiary and home countries political history is critical in the shaping of the political landscape which the cross-border banks. The landscape in the different territories provides for the establishment of appropriate strategies and competitiveness. Managers of cross-border banking have to understand political ideologies governing subsidiaries and headquarters appropriately.

\subsection{Influence of Economic Integration on Cross-border Banking}

The revival of the East African Community in accordance with 1999 East African Treaty (EAT) putting in place mechanisms for a cross-border bank have been put in place to stimulate trade within and outside East Africa. The treaty provides mechanisms for cooperation in trade liberalization and development (EAT, 1999). The various sections of the EAT outline ways for organizations to improve trade across borders; these include: the establishment of customs unions (75) and a common market (76), addressing imbalances arising from customs unions (77), cooperation in investment and industrial development (Chapter 12), promotion of industrial linkages (79), harmonization of macroeconomic policies especially exchange and interest rates and monetary and fiscal policies (82), removal of obstacles to free movement of goods and services and capital (82c), banking and capital market development (85), facilitation of movement of capital 
(86), joint project financing (87), harmonization of telecommunication services (99), and fostering cooperation in education and training (102).

Different respondents had varying opinions in relation to the influence of the East African community on cross-border banking. Despite the provisions of the treaty, the study established that the framework had not provided adequate mechanisms for the enhancement of cross-border banking. One of the respondents argued that "the treaty has good provisions that could accelerate the integration process a pre-requisite for integration, but the process has not been adequately undertaken due to limited knowledge among the stakeholders."Different actors in East Africa are basically undertaking the initiative on their own as the policies don't give adequate mechanisms for implementation. The respective governments' seem to be having reservations while implementing the treaty. One of the respondents argued that "the East African Community is taking time due to reservations among member countries. Tanzania has reservations on the integration process because of benefits accruing from SADC region. There seem to be selfish interests among the member countries, and therefore the dream is taking time."

However, companies that are undertaking cross-border ventures are basically undertaking it in a bid to ensure the dream becomes a reality. East African community policies are not a driving force towards competitiveness as the political leaders are trying to build integration on selfish interests. Collaboration within East African community especially crime prevention and meetings in the region to facilitate discussions on reforms with the region facilitate the integration efforts.

Integration provides mechanisms for the establishment of a common political and socio-cultural environment establishment of similar policies, procedures, political systems, economic systems, and social systems in the East African Community aids in effective cross-border banking. However, the study established that limited efforts had been put in place for the integration of the financial systems in the member countries. It's imperative for the member countries to expedite the process for integration of the East African community. The integration of the community would enhance the competitiveness of the regional banks as opposed to other pan African and other foreign banks.

\section{Conclusion}

Pan-Africanism the movement aims at encouraging and strengthening of solidarity by African people is touted to be a driver for development in Africa. Different approaches have been advanced to ensure integration of African society. The emergence and dominance of African banks in Africa have been touted as one of the popular mechanisms leading to a concept termed as Pan-African cross-border banking. African Banks have become dominant in the African market as opposed to European colonial banks substantially increasing their geographic footprints on the continent. African cross-border banks have become economically significant beyond their home countries and of systematic importance in a number of jurisdictions. This study was commissioned to systematically undertake to examine the influence of the political environment on Pan-African cross-border banking. Kenya Commercial bank was used as a case for studying cross-border banking.

In conclusion, the political environment in the home and subsidiary countries can either be an inhibitor or catalyst in Pan-African cross-border competitiveness. The regional integration and Pan-Africanism has to go beyond just political heretics but should adopt a pragmatic approach in regional and African integration. There has to be a systematic understanding of political elements influencing the political environment and designing of strategic actions to streamline cross-border banking. Regional integration East African Community, South African Community of Economic Community of the West African States and African Union has to streamline the dynamics to capture the critical aspects of the integration. Pan-African banking needs to enhance Pan-Africanism and vice versa. Integration must be systematically undertaken capture political environment that was distorted by history, ideologies, different political systems, different regulatory frameworks between the subsidiaries and home countries. This will further enhance the significance of Pan-African banks African cross-border banks enhancing economic development within Africa.

\section{References}

Becks, T., Fuchs. M., Singer. D., \& Witte, M. (2014). “Making Cross-Border Banking Work for Africa." Eschborn, Germany: Deutsche GesellschaftfürInternationaleZusammenarbeit GmbH.

Berg, B. L. (1989). Qualitative Research Methods for Social Sciences. $4^{\text {th }}$ Edition. Allyn and Bacon. Long beach.

Bornadi, J. P., Hillman, A. J., \& Keim, G. D. (2005). The attractiveness of political markets: implications for firm strategy. Academy of Management Review, 19, 397-413.

Brownbridge, M., Harvey, C. (eds.) (1998). Banking in Africa: the impact of financial sector reform since independence. New Jersey, Africa World Press.

Camillo, A. A. (2015). Global enterprise management. [Electronic book]; new perspectives on challenges and future developments., Palgrave Macmillan Basingstoke. Available online:

http://eds.a.ebscohost.com.ezproxy.liv.ac.uk/eds/detail/detail?vid=20\&sid=778e1a3f-507d-4841-87d0-c41b3f8edf2 
5\%40sessionmgr4001\&hid=4211\&bdata=JnNpdGU9ZWRzLWxpdmUmc2NvcGU9c210ZQ\%3d\%3d\#AN=lvp.b3 677992\&db=cat00003a. (Accessed: $13^{\text {th }}$ November 2015).

Cooter, R., \& Ulen, T. (1988). Law and Economics. New York: Harper Collins.

Cristini, M., Moya, R., \& Powel, A. (2001). The Importance of an Effective legal System for Credit Markets: The Case of Argentina. Foundation of Latin American Economic Research (FIEL). Central Bank of Argentina.

Diaconou, L. (2012). Business Strategies of the Multinational Corporations. CES Working Papers.

Focarelli, D., \& Pozzolo, A. F. (1999). The determinants of cross-border bank shareholdings: an analysis with bank-level data from OECD Countries. Rome: Banca de Italia.

Focarelli, D., \& Pozzolo, A. F. (2005). Where do banks expand abroad? An empirical analysis. Journal of Business, 78, 2435-2463.https://doi.org/10.1086/497052

Gattani. V. (2014). What are BASEL 1, 2 and 3 norms? What are the basic differences between these norms? Quora. Available online at

Gooderham, P. N. (2012). The transition from a multi-domestic enterprise in an industry where local taste matters. European Journal of International Management, 6(2), 175-198.

Gooderham, P. N., Grøgaard, B., \& Nordhaug, O. (2013). International Management: Theory and Practice. Edward Elgar: Cheltenham.

Herrero, A. G., \& Pería, M. S. (2007). The mix of international banks' foreign claims: determinants and implications. Journal of Banking and Finance, 31, 1613-1631. https://doi.org/10.1016/j.jbankfin.2006.11.002

https://www.quora.com/What-are-BASEL-1-2-and-3-norms-What-are-the-basic-differences-between-these-norms. (Accessed: 13 ${ }^{\text {th }}$ March 2017).

KCB (2016). Annual Report. Kenya Commercial Banking Group

La Porta, R., López-de-Silanes, F., Schleifer, A. et al. (1996). "Law and Finance." NBER Working Paper 5661. Cambridge, Mass.: National Bureau of Economic Research. https://doi.org/10.3386/w5661

Larry, H. (2010) CPH Exam Quick Reference Review - Page 82 - Google Books Result. [Online]. Available at: https://books.google.co.ke/books?id=Rhdf22LwbmsC\&pg=PA82\&lpg=PA82\&dq=n+\%3D+\%28z2.p.q\%29+D+d2 \&source=bl\&ots=Mw9uqxOZ1b\&sig=zsFC2vr2eWzAE2pNJy3DGEEr_0c\&hl=en\&sa=X\&redir_esc=y\#v=onepa ge\&q=n\%20\%3D\%20\%28z2.p.q\%29\%20D\%20d2\&f=false. (Accessed: $16^{\text {th }}$ December 2015).

Lundan, S. (2014). Transnational corporations and transnational governance. [Electronic book]: the cost of crossing borders in the global economy. Basingstoke: Palgrave Macmillan.

http://eds.a.ebscohost.com.ezproxy.liv.ac.uk/eds/detail/detail?vid=20\&sid=77c86411-70ea-425e-9392-c876118c8f c1\%40sessionmgr4001\&hid=4211\&bdata=JnNpdGU9ZWRzLWxpdmUmc2NvcGU9c210ZQ\%3d\%3d\#AN=lvp.b3 654046\&db=cat00003a. (Accessed: $14^{\text {th }}$ November 2015).

Shenkar, O., \& Luo, Y. (2008). International business. 2nd ed. Thousand Oaks, CA: Sage Publication.

Strauss, A., \& Corbin, J. (1998). Basics of Qualitative Research Techniques and Procedures for Developing Grounded Theory (2nd edition). Sage Publications: London.

\section{Copyrights}

Copyright for this article is retained by the author(s), with first publication rights granted to the journal.

This is an open-access article distributed under the terms and conditions of the Creative Commons Attribution License which permits unrestricted use, distribution, and reproduction in any medium provided the original work is properly cited. 